\title{
低速風洞による換気用風力係数に関する実験的研究
}

\author{
円形建物飞っいて二

$\begin{array}{clll}\text { 正会員 佐 藤 鑑* } & \text { 同 } \bigcirc \text { 齊 藤 彰** } \\ \text { 同 鈴 }\end{array}$

§1. 序 耐風構造上使用せられる風力係数に関する 従来の実験的研究は、力学的相似条件から Reynold's 数 （以後 RN と記す）を限界 RN 以上とするため、風速が $10 \sim 30 \mathrm{~m} / \mathrm{sec}$ 亿扔いて実験されている。この場合、風洞 の大きさに制約せられて、その模型の大きさも著しく小 さい場合が多い。著者は従来換気や通風を研究するため 亿低速 $(50 \sim 150 \mathrm{~cm} / \mathrm{sec})$ の大型風洞を利用し、内部風速 測定、煙観察等により定性的、定量的資料を求めてきた が、これらの結果はその RNが著しく実物より小であつ ても大方の性質は実物とよく近似し、設計上の予測をす るに有益であることを認めてきた。然しこれらの換気、 通風の現象は所詮風力係数に支配されるるのであるの で、低速風洞で比較的大型模型を使用し、限界 RN 以下 の場合でる風力係数の分布が従来の高速風洞で行われた 結果と如何なる点で相異を示すか、又模型が比較的大型 であるので外壁附加物（庇、袖壁）の影響等もこの風洞 の応用的特色として式験したるのである。

対象模型は従来の高速風洞による資料が比較的多く、 又曲面のため相似条件の不可欠と云われている円形建物 をとりあげた。

§2. 本実験に関する不完全相似性 完全相似の条件 として縮尺を実物の $1 / 40$ とする時、ス (縮尺率) $=40$ で あるから、実物の風速、動粘性係数をそれぞれ $V, N$ と し、模型のそれを $v$, とすると、その条件は、 $V / v=\lambda^{1 / 2}$ ， $N / \nu=\lambda^{3 / 2}$ を満さねね゙ならね。この理論的条件は何れる本 実験とは著しくかけはなれたるのである。Froud 数より 導かれた後者の条件は全く成立せず、前者の RN より導 かれたるのでは、 $\lambda=40$ であるから、V/v $\div 6.3$ となるの で、実験風速 $v$ を、 $50 \mathrm{~cm} / \mathrm{sec}, 100 \mathrm{~cm} / \mathrm{sec}$ とすると、実 物風速な $3.15 \mathrm{~m} / \mathrm{sec}, 6.3 \mathrm{~m} / \mathrm{sec}$ となる。その時には相 似は成立する筈である。然るとこの場合の RN をみる と、温度 $10^{\circ} \mathrm{C}$ 、湿度 $70 \%$ 、大気压 $760 \mathrm{mmHg}$ として、 $\nu=0.141, l=60 \mathrm{~cm}, v=50 \sim 100 \mathrm{~cm} / \mathrm{sec}$ として、 $\mathrm{RN}=$ $2.13 \times 10^{4} \sim 4.26 \times 10^{4}$ となり、この值は限界 RNを遙か に下廻つたものであるから、寸法効果の影響を生ずるこ ととなる。従つて、こなに得られる風力係数は実物に適 用する設計の資料とはなり得ない。特に対象建物が曲面 構造であるので非常に不利なこととなる。それにも拘ら

$*$ 横浜国大教授 工博 ** 新菱冷熱工業 $\mathrm{K} \mathrm{K}$
***
藤森工業 $\mathrm{KK}$

ず、敢えてこの企画を行つたのは、換気、通風の試験に 用いるこの低速風洞による実験飞対し、ぞの程度の信頼 が期待されるか、限界 RN 以上の従来の高速風洞実験飞 対し、如何なる点でその分布に変化を生ずるか等を明か そせんとするのがその目的である。又高速風洞実験に比 乙て模型が比較的大きく、従て庇や袖壁等の外壁附加物 の影響を相対的飞観察することも出来るので、この実験 る併せて報告するるのである。

§1. 実験方法 実物円形建物 1 直径 $24 \mathrm{~m}$, 階高各 $3.6 \mathrm{~m}, 4$ 階建高さ $14.4 \mathrm{~m}$ の $1 / 40$ の縮尺とし、亜鉛引 鉄板で作成し、模型は開口を設けず、内部は実験室に通 ぜしめた。測孔の径は $1.5 \mathrm{~mm}$ で 1 象限とついて各階て 上中下の 3 段とし、各階 21 孔、全階にて 84 孔を用い、模 型を䞟転させて風向、風背を任意に変更出来るようにし た。又屋上については1象限 そ16孔をあけ合計 100 孔に ついて実験された。孔の配 列は第 1 図の通りである。

圧力測定は Chatock の 微圧計を使用した（測定範 团 $1 / 200 \mathrm{~mm} \sim 20 \mathrm{~mm})$ 。風 速測定は感風素子としてサ ーミスターを使用し、電子 管式自動平衡器に接続し、 数回の記録とよつてその平 均を求めたが、今回の実験 では模型のない時の風速分 布に使用したのみである。

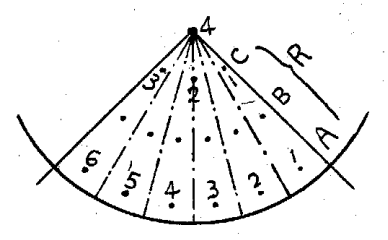

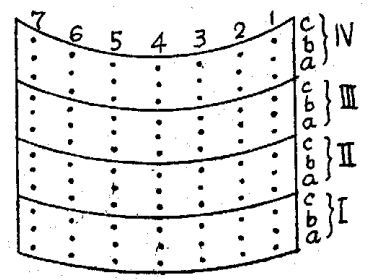

記号 RA1 …… $[a 1, I 62 \ldots$

第 1 図 風洞は Texas Experimental Station の型(1)で風洞気流 の断面は币 $2.3 \mathrm{~m}$ ，高さ $2.0 \mathrm{~m}$ である。Wind Table 上 の風速の垂直分布は整流格子前方 $\mathrm{cm}$ の位置で、中央 80 $\mathrm{cm}$ の巾内での 5 点の平均の垂直分布を第 2 図 (A) 飞示 乙、又中央 $80 \mathrm{~cm}$ 巾内の風速の水平分布を(B) 飞示す。

風力係数の算定には模型が風に対しては閉鎖型であ り、底面が実験室に通じているので、模型内の室内压 $P_{r}$ は実験室の静圧 $P_{s}$ 飞等しいと考光、 $C=\left(P-P_{s}\right) / q$, $\left(q=r V^{2} / 2 g\right)$ 上り求めた(こ」に $P$ は壁面及び屋根面上 り求められる風火上る圧力、 $V$ は風洞内の自由風速、本 実験では $50 \mathrm{~cm} / \mathrm{sec}, 100 \mathrm{~cm} / \mathrm{sec}$ とする) 即ち、その計 算は凡て従来の方法に準じ、既往試験との比較に便なら 
しぬた。実験な最初に附加物のない円筒形について自由 風速 $50 \mathrm{~cm} / \mathrm{sec}, 100 \mathrm{~cm} / \mathrm{sec}$ の場合を行い、従来の理論 值及び高速 風洞実験值 と対照し、 その特性を 明か炕した 上、庇（出 は実物とし $\tau 0.5 \mathrm{~m}$, $1.5 \mathrm{~m}$ の 2 種)、更飞 放射状袖壁 （実物で高 さ $1.4 \mathrm{~m}$,

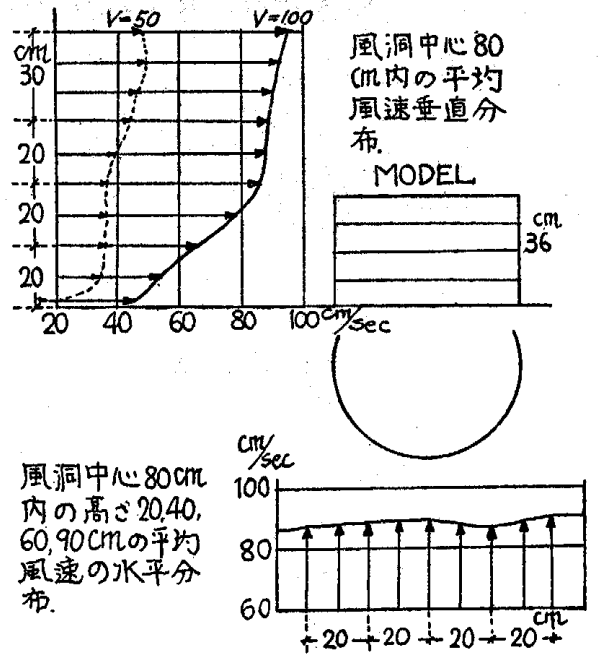

出 $0.6 \mathrm{~m}$ )

を配置した時の影響をみた。

\section{§4. 実験結果とその検討}

（1）附加物のない場合の従来の高速風洞値との比較 この目的のためとは前渦や屋根面への跳躍気流の影響 のない位置として、建物総高さ $H$ の約 0.7 倍の位置の 分布をとることとする（従来の方法）然し Oseen による 理論解では無限円筒を使用して抢り、亀井博士の実物測 定例では $0.87 \mathrm{H}$ となつているが、本試験で $0.7 \mathrm{H}$ とす ると第 1 図に示す 3 階の中央の列、即ち IIb 列にあたる のでこの測定值を以て比較する。第 3 図はとの結果を対 照したものである。

第 3 図深括いて、

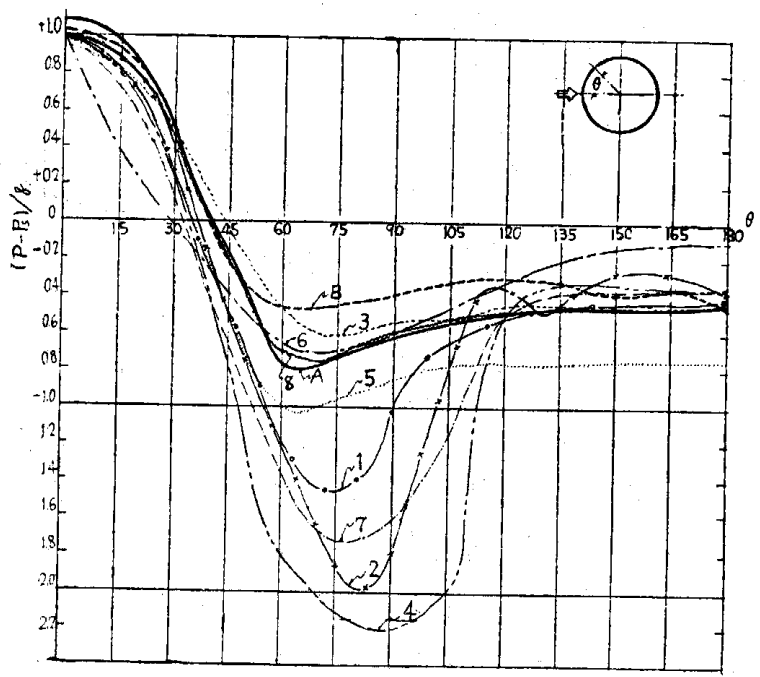

第，3 図

(A): 低速風洞值 (本実験) $v=1.0 \mathrm{~m} / \mathrm{sec}, l=60 \mathrm{~cm}$ $\mathrm{RN}=4.26 \times 10^{4}$

(B)：低速風洞值（本実験） $v=0.5 \mathrm{~m} / \mathrm{sec}, l=60 \mathrm{~cm}$ $\mathrm{RN}=2.13 \times 10^{\circ}$

(1)：Oseen の理論值 ${ }^{(2)}$ (Zeilon の補正とよる)

(2)：高速風洞值 (O. Flachsbart) $)^{(3)}$ MAN タンク、
平滑面 $v=35 \mathrm{~m} / \mathrm{sec}, l=30 \mathrm{~cm}, \mathrm{RN}=6.30 \times 10^{5}$

(3): 同 (O. Flachsbart) ${ }^{(4)}$ KLÖNNE タンク、(粗 面) $v=30 \mathrm{~m} / \mathrm{sec}, l=30 \mathrm{~cm}, \mathrm{RN}=8.60 \times 10^{5}$

(4): 同 (Dryden and Hill) ${ }^{(5)}$ 煙突 $v=80 \mathrm{ft} / \mathrm{sec}$, $l=8^{\prime \prime} \mathrm{RN}=3.36 \times 10^{5}$

(5): 同 (Dryden and Hill) ${ }^{(5)}$ 煙突 $v=40 \mathrm{ft} / \mathrm{sec}$, $l=8^{\prime \prime} \mathrm{RN}=1.68 \times 10^{5}$

(6)：自然風中実物タンク (龟井勇) ${ }^{(6)} v=4.6 \mathrm{~m} / \mathrm{sec}$, $l=12 \mathrm{~m}, \mathrm{RN}=3.34 \times 10^{5}$

(7)：乱流風洞值 (龟井勇) ${ }^{(6)} v=4.6 \mathrm{~m} / \mathrm{sec}$, $l=1.2 \mathrm{~m}, \mathrm{RN}=8.33 \times 10^{4}$

(8): 独逸規格委員会 ${ }^{(7)}$ 粗面の場合の標準

上記一群の実験結果をみると、(3), (5), (6),(8) を除 外して、これを $(\mathrm{A})$ ，(B) と比較すると、大方の傾向は近 似しているが $\theta=45^{\circ} \sim 120^{\circ}$ の範围炡いては、高速風 洞值は低速風洞值比し著しく高い風力係数示してい る。又気流の剥離点 $(c=0)$ の点は低速の方が総じて約 $5^{\circ}$ 程度後方の方によつて括り、風向正圧部では概して低速 の方が大きく、風背 $\left(120^{\circ} \sim 180^{\circ}\right)$ でも低速の方が大きく あらわれている。以上は平滑面模型の高速風洞值との比 較であるが、他の (3),(5)，(6),(8) の傾向は低速風洞值 の傾向と極めて近似している。(3) \& Flachsbart の粗面 タンクで徍 $30 \mathrm{~cm}$, 高さ $58 \mathrm{~cm}$, 高さ $10.6 \mathrm{~cm}$ 毎に突出 $1 \mathrm{~cm}$ の庇状の附加物か 5 個突出し、更飞 $3.9 \mathrm{~cm}$ 毎飞突 出 $0.2 \mathrm{~cm}$ の骨組が出ている。即ら粗面と考兄られるも のである。(2) の平滑タンクと RN が同程度であるにか 〉わらず著しい相異を示し、その傾向は低速風洞值 (A) と非常に近似している。独冕の風荷重規格委員会の報告 では円筒形構造物の表面粗の場合の標準として示してい る風力係数の分布を(8) そ示したが、偶然とは云え、 (A) の分布と全く一致している。(5) は Dryden and Hill の煙突に対する実験であるが、(4) と同一模型に対 乙試験風速を半減した結果の分布であるが、その傾向は 低速風洞值の結果と相似的な変化を示している。(6)は 亀井博士に上り実施された自然風中飞拈汀る径 $12 \mathrm{~m}$ の タンクの実測々定である。この測定結果は低速、高速、 整流、乱流何れの模型実験結果とも異つている。

な扔低速 (A)，(B) は同一模型代対し風速を前者は 100 $\mathrm{cm} / \mathrm{sec}$, 後者は $50 \mathrm{~cm} / \mathrm{sec}$ で何れも RN は限界 RN 上り 遙汃下下迴つている。(2) と（3）の対照、(4) と（5）の 対照、(A) と (B) との対照には興味多いものがある。

以上を綜括すると

1. 低速風洞飞よる風圧分布は、高速風洞に上る分布 そ比して、建物横側の剝離点附近の負圧值が極めて小之 なり、風向正圧值と風背負圧值 $\left(\theta=120^{\circ} \sim 180^{\circ}\right)$ はその 絶対値が他の諸例のうち最も大きい(但し (5) の風背は 例外とする)。

2. 低速風洞による分布は、高速風洞による粗面の場 
合の傾向に近似する。

3. 気流の剝離点 $(c=0)$ は高速風洞では約 $\theta=35^{\circ}$ 前 後にあるが低速風洞では $40^{\circ}$ 前後になる。

4. 側面飞抬いて最大負圧を与兄る $\theta$ は高速風洞では $75 \sim 90^{\circ}$ とあるが、低速風洞、高速粗面模型、自然風実

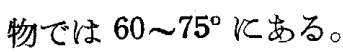

(2) 測定点の高されよる差 前項飞捺いては $0.7 \mathrm{H}$ の測定点のみを対照したが、低速風洞によつた時の測定 点の高さに上る差をみる。本測定では $v=100 \mathrm{~cm} / \mathrm{sec} の$ 時のみを記す $(50 \mathrm{~cm} / \mathrm{sec}$ の時はPが非常に小さいので 精度に疑問があるから以下の報告では省略する)。第 4 図はその結果である。測定点は第 1 図の $\mathrm{Ib}, \mathbb{I a}, \mathbb{I c}$, IIIb, $\mathrm{IVa}, \mathrm{IV} c$ c 6 列である。低位置にあたる Ib, II 乙負圧值梳比的小さく, 変動子少い。中央位置の Ic , IIb, IV a 略々近似し、 $\theta=60 \sim 75^{\circ}$ で負压最大を示してい る。最高位置 $\mathrm{IVc}$ は正圧值も著しく低く、中央附近とは 異つた分布を示す。正圧値の低いのは気流が屋上飞跳躍 するためであり $\theta>75^{\circ}$ で負圧值が増大するのは屋根面

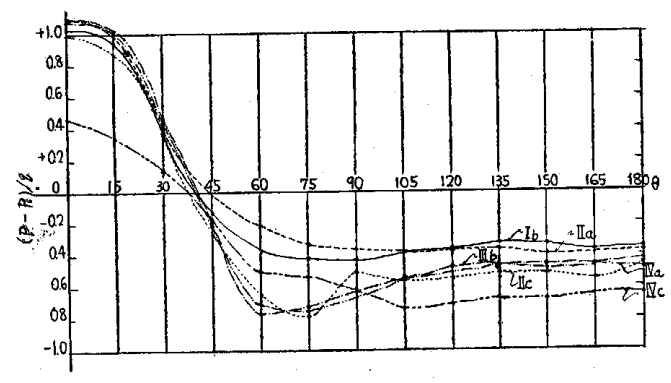

第 4 図

飞跳躍せる気流 が $\theta=90^{\circ}$ の線 以下で下降し、 屋根面飞沿つて 流れる気流の誘 引のためと思わ れる。屋根面の

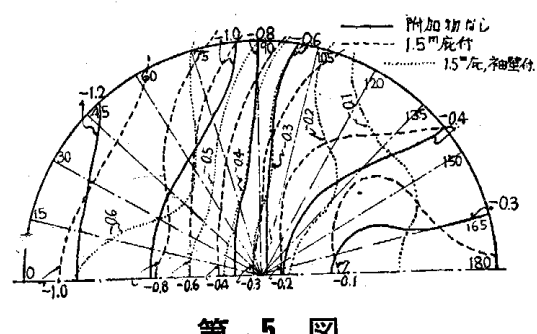
第 5 図

分布は第 5 図 (実線) の通りである。

以上の諸性質の主なる点は高速風洞によるFlachsbart のタンクの実験にす認められる。

（3）庇を附加した時の分布・模型飞拓いて突出 $1.25 \mathrm{~cm}$ 又は $3.75 \mathrm{~cm}$ の庇を各階驸した時は、円形模 型の正圧側の表面を流れる流れは 2 次元的な制約をうけ るらしい。従つて各階の $a, b, c$ (第 1 図) の測点飞よる 変化は少くなり、非常飞安定した測定值が得られた。各 階の $a, b, c 3$ 点をそれぞれ平均して、各階の分布として 示すと、突出 $1.25 \mathrm{cu}$ (実物 $50 \mathrm{~cm}$ ) の時が第 6 図であ り、突出 $3.75 \mathrm{~cm}$ (実物 $1.50 \mathrm{~cm}$ ) の時が第 7 図である。 先づ庇を附することにより、ない場合に比して剥離点が 後退しているが、第I階のみは前方と移動している。風 向正圧 る庇のある時は第 I 階のみは低下している。又仳

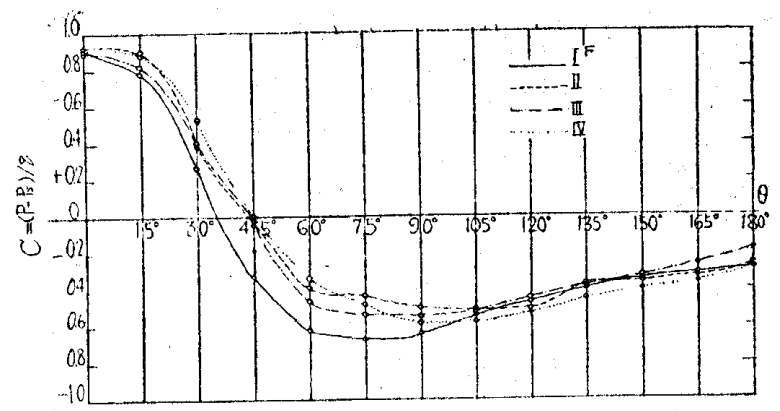

第 6 図

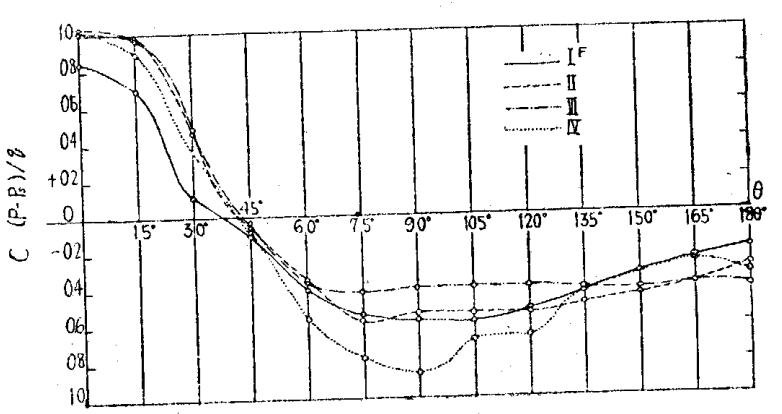

第 7 図

のない場合の第 IV 階の特質（第 4 図 IVc) は庇の大小火 拘らず消失し、第 II, III 階では剝離点から $\theta=105^{\circ}$ まで の負圧飞顕著な低下が消失している。庇の出の少い場合 は第 I階以外殆ど近似した分布を示し、仳の出の大き い場合は第IV階のみが稍々異状な分布を示す。この理由 は明かでない。全般的とみて庇のある時は、これのない 場合の下方（第 4 図 Ib, Ia）の傾向飞近似してくるよう である。

このことは上向する気流の制約とよるすのではないか と思われる。最子重要と考兄られる点は庇の有無による 差が、Flachsbart の実験した MAN 式タンク（平滑）と KLÖNNE 式タンク（仳、柱等の附加物あり）との差（第 4 図 (2)，(3)）にみるような大きな変化をみないことで ある。

な招風力係数の分布をその垂直方向の分布でみると、

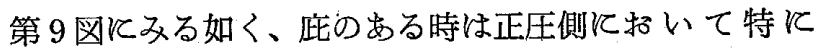
I，II 階の間で著しい不連続分布を示すが、II階以上は 不明瞭であり、負圧側では略々連続している。このこと は正圧側では庇によつてＩ階の気流の性状が而階以上と 異つていることを示するのと思われる。

な打屋根面汸ける風力係数の分布は、 $1.5 \mathrm{~m}$ の庇付 の場合を第 5 図の破線に示すが、全般的に負压の低下を 生じている。

（4） $3.75 \mathrm{~cm}$ 庇之放射袖壁 $(3.5 \mathrm{~cm} \times 1.5 \mathrm{~cm}) 8$ 枚を 配せる場合・袖壁の配列は第 8 図 (A) 飞示す。各階 3 点の測定值の平均を以て、その分布を示したものが同図 (B) である。この結果の著しい特色は風向側 $\theta=0 \sim 90^{\circ}$ までの間の 2 枚の袖壁で風力係数の顕著な不連続線を生 じたととで、気流の剝離点は消失し、 $\theta=67.5^{\circ}$ まで正圧と 


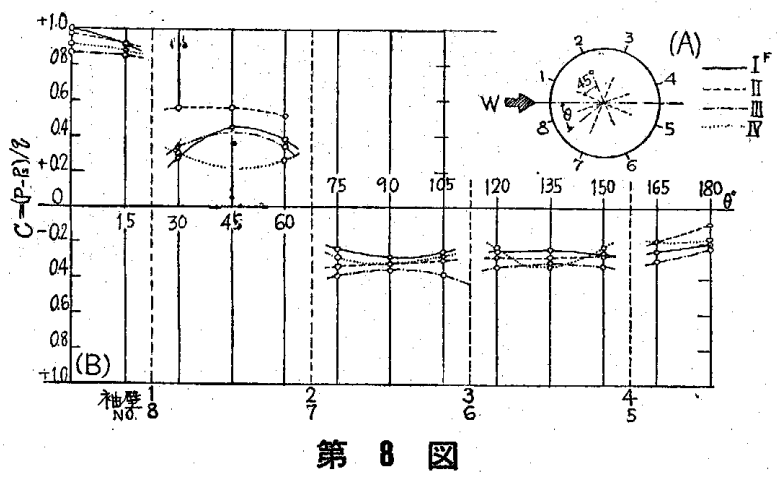

が近似している。剥離点直後のCの飛躍的増加は低速風 洞では生じない。理論的根拠を保留すれば、换気通風の 性状判定に标汀る低速風洞の応用は十分みこみのある方 法と考克られる。

著者が先に実施した円形建物の通風に関する模型実験 及び実物測定の結果とる対照すると、定性的には十分に 信頼出来る試験方法と考穴られる。但し定量的問題飞就 てはな招研究の余地があるが、相対的なある程度の推定 とは役立ち得るであるう。

2. 仳の附加は風力係数の分布
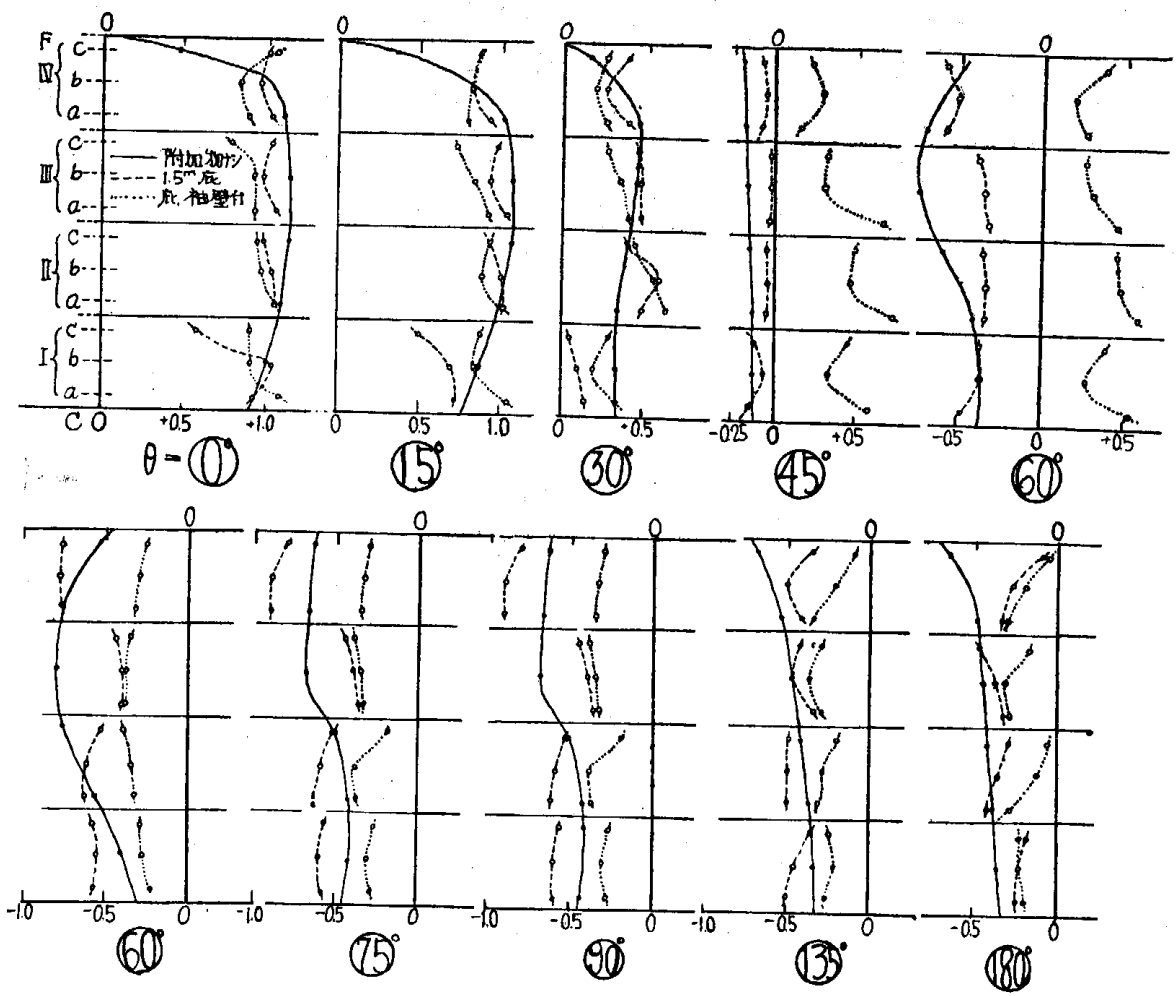

第 9 図

なつたことである。然し $\theta=67.5^{\circ}$ 以上の風背側では、全 般的飞負圧が減少し、袖壁による不連続性も顕著でない。

これを垂直分布に就てみると、第 9 図の如く $\theta=45$, $60^{\circ}$ で政のみの場合と著しい差を示す。この場合に扔い ても風向側の I, II 階の間の不連続が顕著で、II階以上 は明かでなく、風背側では殆ど連続的である。な挍、風 背側の負圧は他の例飞比して小さく、又この場合の屋根 面の分布は第 5 眓の点線に示す如く、更に負圧は低下し ている。

\section{§5. 結 論}

1. 低速風洞に上る平滑面模型の風力係数の分布は、 高速風洞による粗面の風力係数の分布に近似した側向を 示し、剝離点近くの後方の負圧が低下寸る。そして高速 風洞による粗滑の著しい差は、低速風洞では認められ ぬ。実物自然風による刍井氏の調查と比較すると高速風 洞平滑模型によつた分布より低速風洞によつたものの方
飞多少の変化を生ずるが、それは 気流の跳踓が減じて、建物表面が 2 次元的流動の影響をうけるため である。特て前渦の影響をうける 風向側下階の流れ之風向側 2 階以 上の流れとが別個の性状を持つる のの様である。剝離点より後方の 風背側ではその様な変化は認めら れない。

3. 袖壁はこの円形建物に就て は風向側で極めて顕著な変化を生 ずる。即ちこの風向側では袖䇒に よつて剶離点は消失し、袖壁のな い時に負圧をろけた部を正圧に変 ぜしめることが出来る。このこと は間仕切の位置と袖壁の位置との 相互関係により、通風換気の促進 そ有効な手段となり得るである う。

[文 献]

(1) E.G. Smith : The Feasibility of Using Models for Predetermining Natural Vent, Texas, Research Report No. 26, 1951

（2）本島仁訳：粘性流体力学 (W. Müller)

(3) Flachsbart: Windruckmessungen an einem Gasbehälter, Ergebnisse der Aerodynamischen Versuchaustalt zu Göttingen, II Lieferung, 1935

(4) Flachsbart: Winddruck auf Gasbehälter, E. der A.V. zu Göttingen, IV Lieferung, 1932

(5) Dryden and Hill : Windpressure on Circular B.S.J.R. Vol. 51930

（6）亀井勇: 構造物の風圧力関する研究、建築研 究所報告 No. 16, No. 17, 1955

（7），独逸規格委員会報告 1934.9月 5 日（建築雑誌 昭 10,2 月抄録)

（8）佐藤 鑑：円形校舎の通風化関する研究、建築学 会論交報告集 No. 54 , 昭 31.9 Cylinders and Chimneys. Chap. III, Model Ex. 